\title{
Fanconi Anemia Group A Protein
}

National Cancer Institute

\section{Source}

National Cancer Institute. Fanconi Anemia Group A Protein. NCI Thesaurus. Code C85882.

Fanconi anemia group A protein (1455 aa, $163 \mathrm{kDa}$ ) is encoded by the human FANCA gene. This protein may be involved in both DNA damage repair and cell cycle checkpoint regulation. 